\title{
Implementasi e-Government Pada Kelurahan Pesurungan Lor Kota Tegal Berbasis Service Oriented Architecture (SOA)
}

\author{
Oman Somantri ${ }^{1, *)}$, Indra Dwi Hasta ${ }^{2}$ \\ ${ }^{1}$ Jurusan Teknik Informatika, Politeknik Harapan Bersama \\ ${ }^{2}$ Jurusan Teknik Komputer, Politeknik Harapan Bersama \\ 1,2JIn. Mataram No.09 Pesurungan Lor Kota Tegal, 52147, Indonesia \\ email: ${ }^{1}$ oman.somantri@ poltektegal.ac.id, ${ }^{2}$ hasta66@yahoo.com,
}

\begin{abstract}
Services carried out by government institutions which are optimal, effective and in accordance with the standard is a standard part of every institution in Indonesia. To realize the optimum service requires a good system and integrated from the central to the local level. E-Government is an integrated system with the use of media in implementation of information technology. E-Government implemented in Pesurungan Lor village Tegal is currently still has limitations in the implementation of e-Government. Service Oriented Architecture (SOA) is proposed to optimize the built system so as to have the opportunity to be further developed, especially on web service model for optimizing e-government. From the results of research, it shows that the implementation e-Government in the government institution that has not provide yet more optimal improvement of services in the community, especially in the institution at the parish level.
\end{abstract}

Intisari - Pelayanan yang dilakukan oleh institusi pemerintah secara optimal, efektif dan sesuai dengan standar merupakan bagian dari standar setiap intitusi di Indonesia. Untuk mewujudkan pelayanan yang optimal memerlukan sebuah sistem yang baik dan terintegrasi mulai dari tingkat pusat sampai pada tingkat daerah. E-Government merupakan sebuah sistem terintegrasi dengan menggunakan media teknologi informasi dalam pelaksanaannya. E-Government diimplementasikan pada kelurahan Pesurungan Lor Kota Tegal yang saat ini masih mempunyai keterbatasan dalam penerapan e-Government. Service Oriented Architecture (SOA) diusulkan untuk dapat mengoptimalkan sistem yang dibangun sehingga mempunyai peluang untuk dikembangkan lebih jauh lagi khususnya pada model web service untuk optimaliasi $e$ government. Dari hasil penelitian menunjukan implementsi $e$ Government pada intitusi pemerintahan terlebih yang belum mempunyai dapat memberikan sebuah peningkatan pelayanan yang lebih optimal pada masyarakat terutama pada instansi di tingkat kelurahan.

Kata Kunci - E-Government, kelurahan, Service Oriented Architecture.

\section{PENDAHULUAN}

Perananan pemerintah dalam memberikan sebuah layanan terhadap masyarakat menjadi prioritas, hal ini menjadikan

*) penulis korespondensi (Oman Somantri)

Email: oman.somantri@poltektegal.ac.id berbagai fasilitas layanan yang digunakan oleh pemerintah selalu mengedepankan kepuasan pelayanan, efektifitas pelayanan dan efisiensi dalam pengelolaannya. Hal inilah yang menjadikan pemerintah selalu berupaya memberikan yang terbaik kepada masyarakat yaitu dengan cara meningkatkan pelayanan, salah satunya adalah dengan membuat suatu sistem berbasis teknologi informasi secara terintegrasi antar lembaga pemerintahan untuk meningkatkan pelayanan. Salah satu bentuk pelayanan yang diberikan pemerintah adalah membangun sebuah konsep $e$-Government pada setiap tingkatan instansi pemerintah.

E-Government merupakan sebuah proses pemanfaatan teknologi informasi sebagai alat bantu pemerintah dalam menjalankan sistem pemerintahan secara efisien yang dapat meningkatkan hubungan pemerintah dengan pihak lain. $E$ Government adalah sebuah upaya untuk mengembangkan penyelenggaraan pemerintahan yang berbasis teknologi informasi dalam rangka meningkatkan kualitas layanan publik secara efektif dan efisien. Standarisasi dalam pengelolaan $e$ government di Indonesia sudah mulai distandarisasi untuk mendapatkan sebuah system e-Government yang terbaik sehingga keberadaaanya menjadi salah satu bentuk dukungan teknologi informasi dan komunikasi dalam mendukung admninstrasi pemerintahan mulai dari bagaimana menjembatani komunikasi antara pemerintah dengan masyarakat (Government to Citizen), pemerintah dengan kalangan bisnis (Government to Business), serta pemerintah dengan instansi pemerintah [1]. Selain itu standarisasi $e$ Government menjadi lebih detail dengan mengacu kepada standarisasi model data dan interface yang akan diimplementasikan [2].

Berbagai pengembangan dalam peningkatan kualitas $e$ Government dilakukan oleh beberapa peneliti seperti mengembangkan konsep model interoperabilitas antar aplikasi e-Government. Pada penelitian ini mengusulkan sebuah konsep model interopabilitas untuk pengembangan aplikasi e-Government di Indonesia melalui pemanfaatan teknologi web services [3]. Selain itu hal yang sama dilakukan mengusulkan framework interoperability $e$ goverment untuk pengembangannya [4]. Evaluasi mengenai keberadaan e-Government di Indonesia saat inipun sudah banyak dilakukan seperti salah satunya yang dilakukan oleh 
Handayani, P.W \& Kardia, N.P menganalisis tingkat implementasi e-Government pada level kementrian Indonesia berdasarkan framework Deloitte dan Touche [5]. Sosiawan, E.A melakukan hal yang sama yaitu meneliti terkait dengan evaluasi implementasi e-government pada situs web pemerintah daerah di Indonesia dilihat dari perspektif konten dan manajemen [6].

Kelurahan Pesurungan Lor kota Tegal merupakan sebuah lembaga instansi pemerintahan di kota Tegal pada tingkat kelurahan yang mempunyai tugas melayani masyarakat diwilayahnya. Terkait dengan pelayanan administrasi pemerintahan, sebagai instansi pemerintahan yang dituntut untuk dapat memberikan pelayanan yang optimal maka segala upaya harus dilakukan karena selama ini pada kelurahan Pesurungan Lor masih belum mempunyai sistem terintegrasi yang dapat menunjang peningkatan pelayanan tersebut. Salah satu hal yang bisa dilakukan adalah adanya pembangunan sebuah e-Government kelurahan Pesurungan Lor. Untuk membangun dan mengembangan sistem ini tentunya harus diimbangi dengan sumber daya, infrastruktur serta teknologi yang sesuai. Permasalahan yang terjadi di instansi tersebut adalah bagaimana membangun sebuah e-Government yang memiliki fasilitas service terbaik bagi masyarakat sekitar.

Sebagai pengembangan yang dapat diterapkan pada pembangunan e-Government adalah dengan diterapkannya sistem Service Oriented Architecture (SOA). SOA adalah salah satu model terbaik yang dapat diterapkan dalam pembangunan dan pengembangan E-Government. Service Oriented Architecture (SOA) merupakan pendekatan yang menjadikan fungsi-fungsi aplikasi sebagai service, yang dipaket sebagai komponen yang dapat digunakan ulang serta bersifat independent [7].

Tujuan dari penelitian ini adalah membangun sebuah aplikasi e-Government berbasis web pada kelurahan Pesurungan Lor Kota Tegal sehingga adanya sebuah peningkatan pelayanan bagi masyarakat sekitar menjadi lebih baik dan lebih optimal. Disamping itu, untuk dapat meningkatkan performa sistem yang lebih baik maka pada penelitian ini diterapkan sebuah metode dengan menggunakan pendekatan Service Oriented Architecture (SOA) dengan harapan kedepannya dapat mendukung pada penerapan impelemantasi system web service.

\section{PENELITIAN YANG TERKAIT}

Penelitian terkait dengan pembangunan dan pengembangan e-Government berbasis Service Oriented Architecture (SOA) telah banyak dilakukan. Fajar, A.D., dkk (2013) melakukan penelitian penerapan ZEF Framework untuk aplikasi e-Government dengan menggunakan pendekatan sinergi BPM (Business Process Model) dan SOA (Service Oriented Architecture). Penelitian ini menghasilkan sebuah sistem yang dapat menjembatani bisnis dan IT karena dapat mengidentifikasi, mengklasifikasi serta mengelola commonality dan variability fitur berdasaarkan regulasi sehingga dapat mengurangi dampak biaya akibat perubahan regulasi terhadap aplikasi yang ada [8].
Shofa, A.R.N., dkk (2013) melakukan penelitian menerapkan Service Oriented Architecture (SOA) untuk pembangunan Web Base Learning. Dari hasil penelitiannya bahwa aplikasi yang dibuat dapat membantu proses perkuliahan menjadi lebih baik lagi serta dapat dijadikan sebagai pelengkap pada proses belajar mengajar. Penelitian yang dilakukan juga berdampak terhadap dosen dalam hal mempermudah kinerja dosen dalam memberikan informasi, materi, tugas, serta dapat mempermudah mahasiswa dalam mendapatkan informasi, materi dan pengumpulan tugas kepada dosen [9].

Perdananugraha, G.M (2010) meneliti untuk merancang bangun dan mengimpelemntasikan sistem informasi terintegrasi (Integrated Information System) e-Goverment yang berbasis Open Source. Sistem yang dirancang menggunakan paket open source CMS (Content Managenet System) Joomla yang mampu menggali dan mengangkat potensi informasi yang dimiliki oleh Unit Pelaksana Teknisbalai Informasi Teknologi LIPI [10]. Penelitian berikutnya dilakukan oleh Sutanta, Edhy \& Mustofa, Khabib (2012) meneliti terkait dengan kebutuhan web service untuk sinkronisasi data antar sistem informasi dalam e-Government di Pemkab Bantul Yogjakarata [11].

Selanjutnya penelitian dilakukan Stoica, E.A, dkk (2013) dalam penelitiannya mengusulkan sebuah model untuk $E$ Business dan E-Government serta prosesnya pada Sosial Media [12]. Sedikit berbeda dengan apa yang diteliti oleh Sabucedo, L.M.A., dkk (2009) mengusulkan untuk menyediakan model yang berorientasi pada data model dan interface untuk layanan e-Government dengan menggunakan pendekatan semantic Driven [13].

\section{E-GOVERNMENT DAN SERVICE ORIENTED ARCHITECTURE (SOA)}

\section{A. E-Government}

E-Goverment adalah sebuah sistem interaktif komunikasi dan koordinasi anatara pemerintah dan warganya, badan usaha, dan unit pemerintah lainnya melalui penggunaan teknologi elektronik berbasis web dan lainnya [14]. EGovernment merupakan penggunaan teknologi informasi dan komunikasi dan aplikasinya oleh pemerintah dalam hal penyediaan informasi dan layanan publik bagi masyarakat [15].

e-Government (e-Gov) adalah penggunaan informasi yang dapat meningkatkan hubungan antara pemerintah dan pihakpihak lain yang didalamnya melibatkan komputersisasi pada prosedur paper-based yang akan mendorong cara baru dalam kepememimpinan, cara baru dalam mendsikusikan dan menetapkan strategi, transaksi bisnis, mendengarkan warga dan komunitas serta cara baru dalam mengorganisasi dan menyampaikain informasi [16].

Di negara Indonesia berdasarkan Inpres nomor 3 Tahun 2003 untuk menjamin keterpaduan sistem pengelolaan dan pengolahan dokumen dan informasi elektronik dalam mengembangkan pelayanan publik yang transparan, pengembangan e-Government pada setiap instansi harus berorientasi pada kerangka arsitektur seperti pada gambar 1 . 


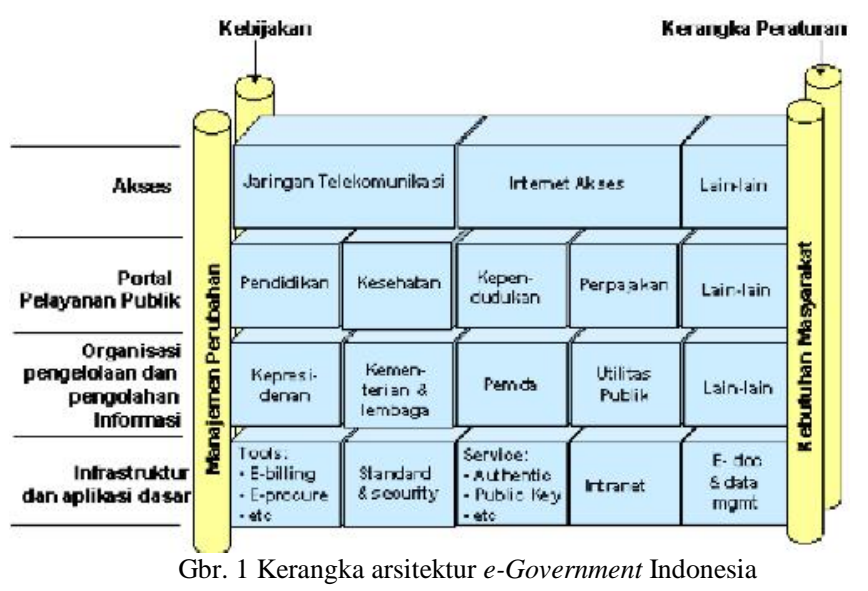

B. Service Oriented Architecture (SOA)

SOA atau Service Oriented Architecture konsep dasarnya adalah penggabungan antara bisnis, teknologi dan manajemen IT [17]. Dari segi persfektif bisnis, SOA merupakan satu set layanan yang digunakan untuk meningkatkan kemampuan organisasi untuk melakukan bisnis dengan konsumen, sedangkan dari sudut pandang teknologi SOA ditandai dengan adanya modularitas yaitu penggunaan kembali layanan, metode pemrograman baru berdasarkan standar, dan tools yang melibatkan layanan web. Sedangkan dari persfektif manajemen IT, SOA memberikan metode baru untuk merancang portofolio aplikasi IT, selain itu implementasi SOA membawa tantangan baru terkait dengan pengorganisasian, tata kelola IT dan perubahan manajemen.

SOA merupakan arsitektur yang mendukung integrasi bisnis layanan yang tehubung dan menjadi jalan menuju inovasi. SOA juga menjadi strategi bisnis berbasis teknologi dan hasil evolusi untuk mengintegrasi berbagai sumber informasi dari sumber kode atau platform yang berbeda-beda. SOA sendiri merupakan sebuah bentuk teknologi arsitektur yang mengikuti prinsip-prinsip service-orientation [18].

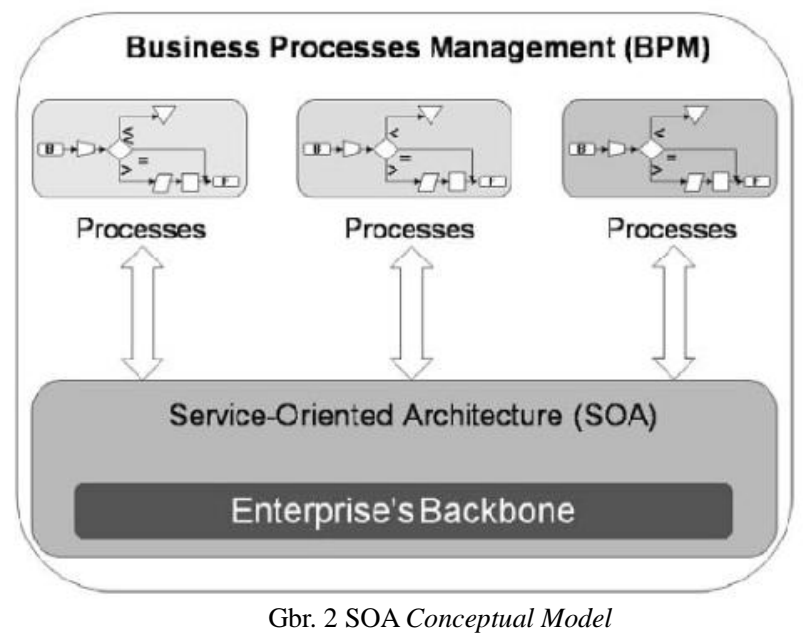

Pada gambar 2 diatas, merupakan sebuah gambaran konseptual SOA sebagai layanan dalam artian sebagai sarana integrasi antara berbagai proses bisnis dan Business Processes Management (BPM) [19].

\section{A. Pengumpulan data}

\section{METODE PENELITIAN}

Untuk membuat system yang diusulkan terdapat beberapa data yang harus didaiapatkan baik itu data primer maupun data sekunder. Data didapatkan dengan melakukan beberapa cara diantaranya: (1) interview user, pada kegiatan ini interview dilakukan kepada user pengguna langsung yakni pihak kelurahan Pesurungan Lor Kota tegal; (2) studi literatur, hal ini dilakukan untuk mendapatkan referensi terkait dengan teknologi yang diterapkan untuk membangun sistem baik itu melalui jurnal-jurnal penelitian, buku, maupun data yang didapatkan di internet.

\section{B. Tools Yang Digunakan}

Pada pengembangan e-Goverment pada penelitian ini menggunakan Adobe Dreamweaver untuk mendesain tampilan web dengan menggunakan bahasa pemrograman PHP, serta Adobe Fhotoshop dan Corel Draw sebagai alat bantu dalam desain tampilan web agar menjadi lebih menarik.

\section{Metode Pengembangan System}

Metode yang digunakan dalam pengembangan system $e$ Government adalah dengan menggunakan UML. Pada proses pengembangan sistem ini menggunakan metode Object Oriented System Development, dimana terdiri dari tiga tahapan proses utama yaitu Analysis, Design dan Implementation. Adapun gambaran metode pengembangan sistem tersebut diperlihatkan pada gambar 3 di bawah ini:

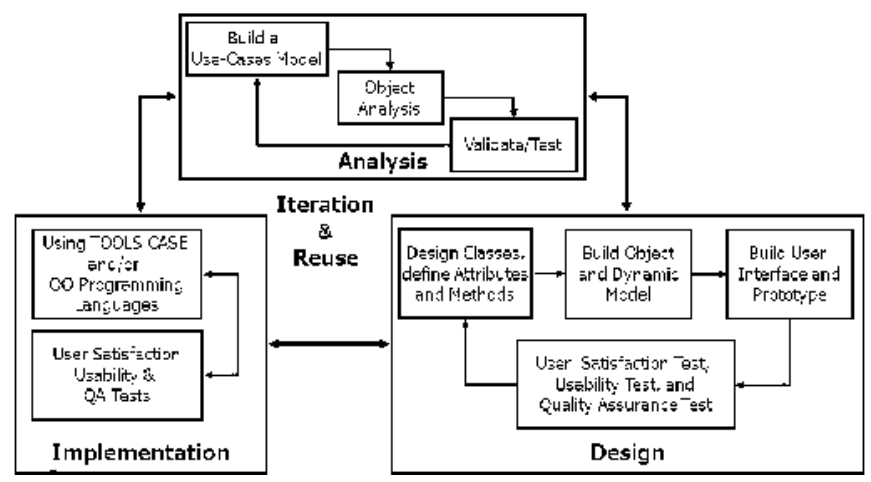

Gbr. 3 Metode Pengembangan Sistem Object Oriented System Development

Pada gambar diatas bahwa model pengembangan sistem dilakukan dengan melakukan beberapa tahapan, diantara:

1) Analysis, pada tahapan ini dilakukan analisis dengan melakukan beberapa hal diantaranya adalah pembuatan model diagram use case, menganalisis objek yang digunakan, serta menganalisis bentuk validasi dari sistem yang akan dibuat.

2) Designe, pada tahapan ini dilakukan beberapa tahapan diantaranya adalah design class diagram, model objek, membangun rancangan interface, serta melakukan test 
usability untuk mengetahui keberhasilan dari sistem yang kita buat apakah dapat diterima user atau tidak.

3) Implementation, tahapan ini adalah pengimplementasian sistem dengan menggunakan tools software dengan bahasa pemrograman berorientasi objek.

\section{Evaluasi System}

Untuk mendapatkan sebuah implementasi sistem yang sesuai dengan yang direncanakan, pada tahapan ini dilakukan sebuah evaluasi sistem untuk dapat memperlihatkan apakah sistem yang dibuat sesuai dengan perencanaan atau tidak. Pada penelitian ini evaluasi sistem menggunakan metode black box. Black box adalah metode pengujian perangkat lunak yang menguji fungsionalitas aplikasi tersebut, sehingga pengujian yang dilakukan adalah mengamati hasil eksekusi melalui data uji dan memeriksa fungsional dari perangkat lunak.

\section{HASIL DAN PEMBAHASAN}

Dalam perancangan sistem terkait dengan implementasi sistem, dilakukan perancangan dan desain sistem yang akan digunakan diantaranya yaitu analisis kebutuhan system, use case, activity diagram, dan class diagram. Pada penelitian yang dilakukan ini menggunakan processor i5 Intel Core 2,67 $\mathrm{GHz}$ dengan memori $4 \mathrm{~GB}$, menggunakan sistem operasi Windows7 SP1 32-bit.

\section{A. Use Case Diagram}

Perancangan diagram use case yang dibuat sesuai dengan pada gambar 4 .

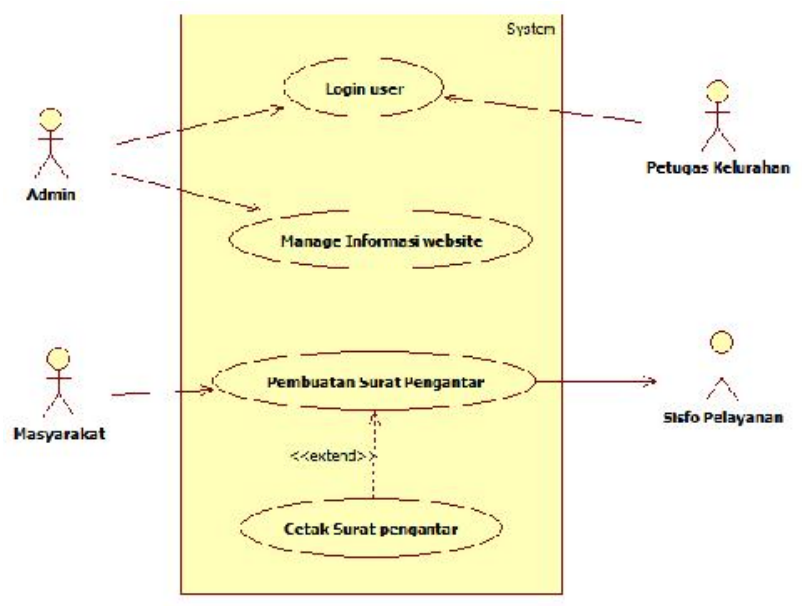

Gbr. 4 Use Case Diagram

Pada gambar 4 memperlihatkan aktor yang berperan dalam system terdiri dari admin, petugas kelurahan dan masyarakat. Admin berperan sebagai pengelola informasi isi website e-Goverment serta informasi lainnya terkait dengan konten website tersebut. Masyarakat sebagai aktor dalam ini mempunyai akses dalam pembuatan surat pengantar yang akan dilayani oleh petugas kelurahan sebagai operator system.

\section{B. Activity Diagram}

Aktifitas masyarakat dalam activity diagram adalah dimungkinkannya masayarakat untuk dapat berkomunikasi dengan pihak kelurahan pesurungan lor melalui media interface aplikasi e-Government, salah satunya adalah pada saat pembuatan surat pengantar.

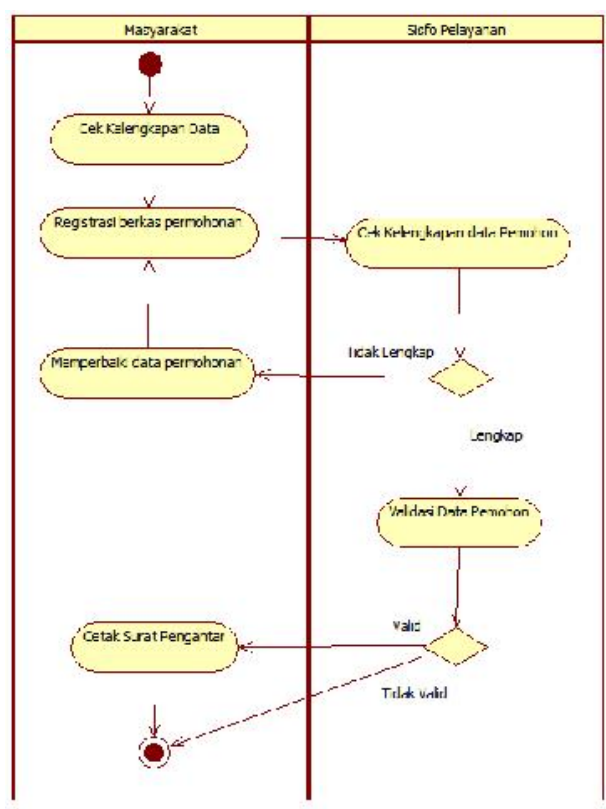

Gbr. 5 Activity Diagram

\section{Class Diagram}

Diagram pada gambar 6 dibawah adalah merupakan gambaran dari class diagram aplikasi e-Government yang diusulkan pada kelurahan Pesurungan Lor Kota Tegal.

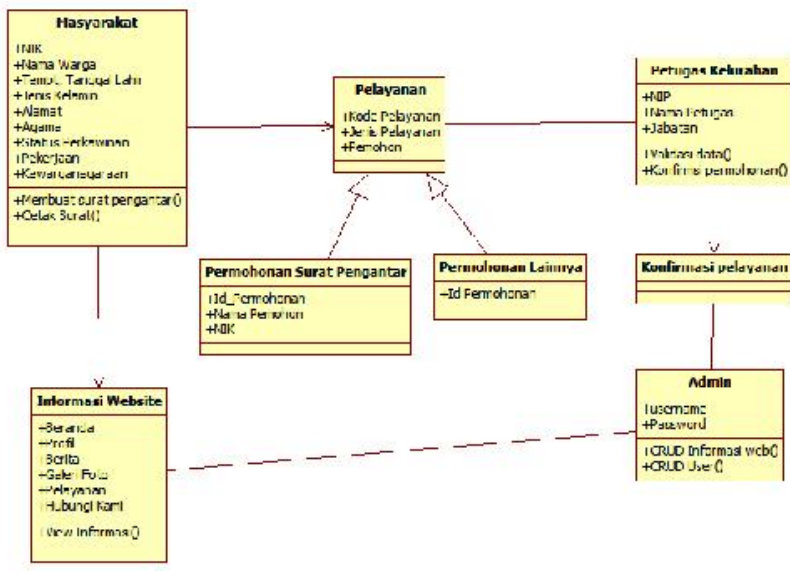

Gbr. 6 Class Diagram

Class diagram pada gambar 6 diatas merupakan proses dari system yang diusulkan pada penelitian ini. 


\section{Implementasi Sistem}

- Tampilan halaman utama

Pada tampilan menu utama, ditampilkan informasi terkait dengan beberapa informasi seperti profil, berita, agenda, galeri, pelayanan, serta menu hubungi kami, seperti pada gambar 7.

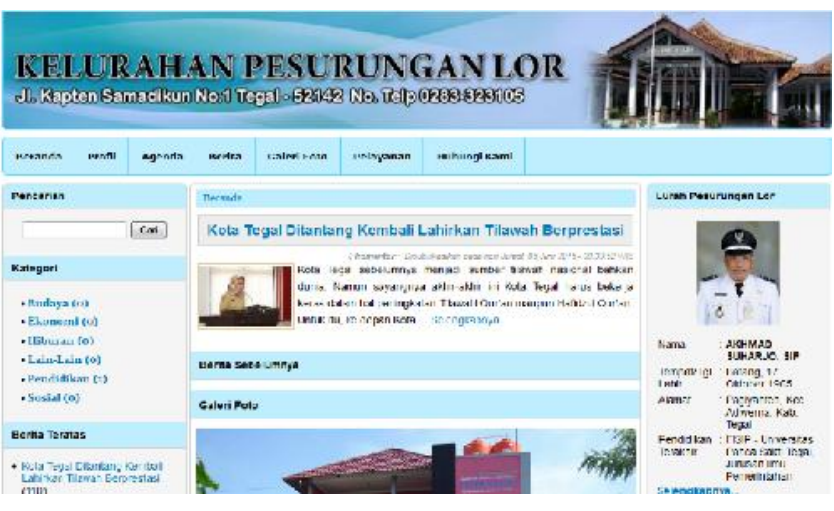

Gbr. 7 Interface tampilan halaman utama.

Pada tampilan utama tersebut juga ditampilkan fhoto profil dari lurah kelurahan Pesurungan Lor.

\section{- $\quad$ Menu Pembutan Form Surat Pengantar}

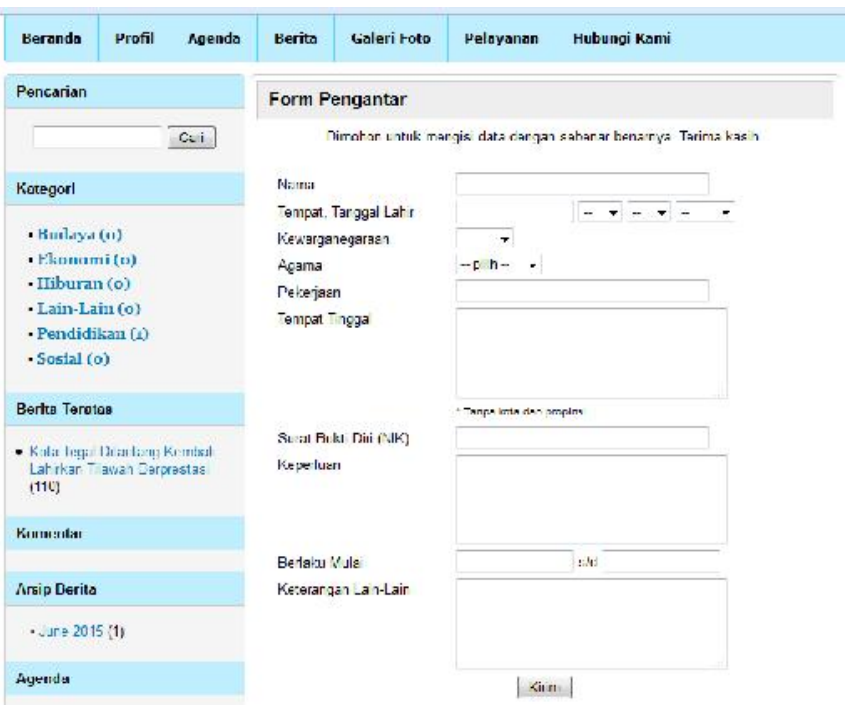

Gbr. 8 Interface tampilan Form pengantar

Pada form surat pengantar, user dalam hal ini masysrakat dapat menggunakan akses tersebut untuk dipergunakan memeperoleh surat pengantar dari kelurahan. Form pengantar ini terdapat pada menu Pelayanan.

- Tampilan struktur organisasi

Pada menu profil selain ditampilkan profile, ditampilkan pula struktur organisasi yang ada di kelurahan pesurungan Lor.

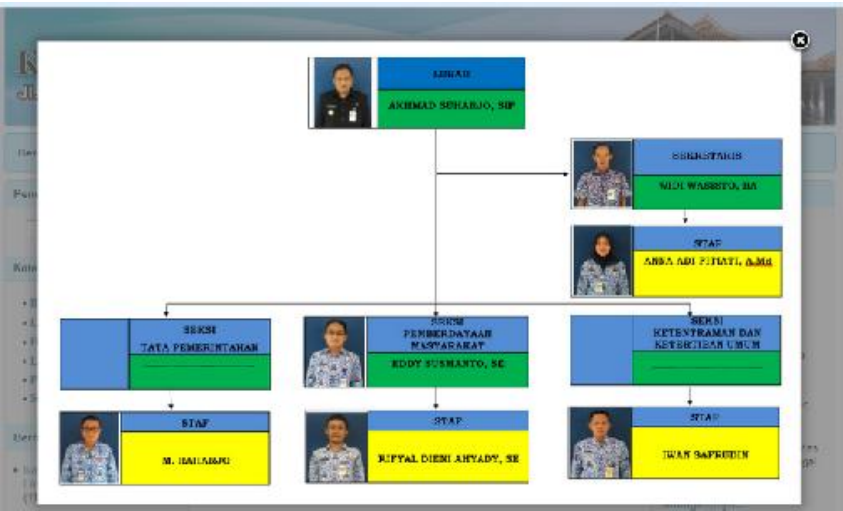

Gbr. 9 Interface tampilan struktur organisasi.

Gambar 9 diatas menunjukan interface tampilan struktur organisasi kelurahan pesurungan lor Kota Tegal.

\section{- Tampilan Peta wilayah}

Untuk memudahkan user dalam hal ini masysrakat lebih mengenal kembali dengan pemerintahan di kelurahannya, maka ditampilkan terkait dengan kondisi umum wilayah berserta dengan peta batas wilayah kelurahan Pesurungan Lor.

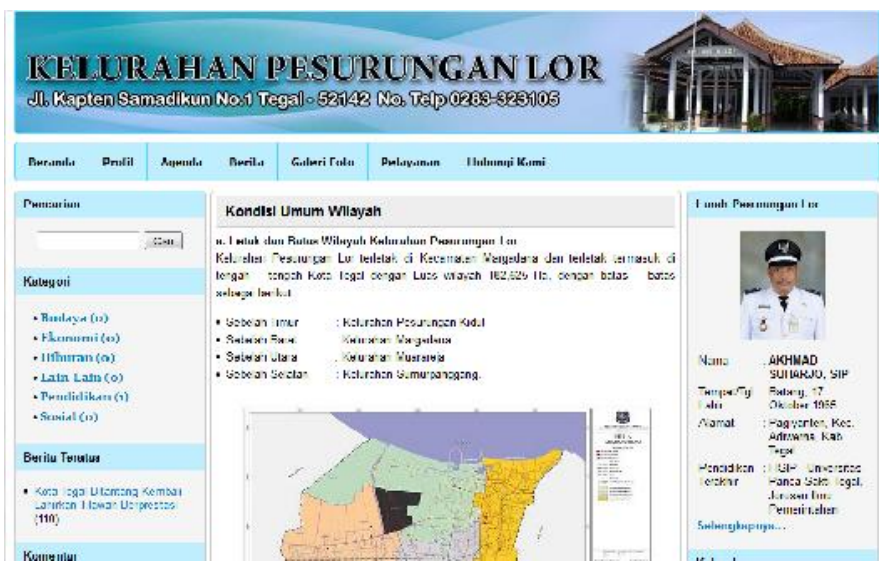

Gbr. 10 Interface tampilan halaman utama

\section{E. Evaluasi System}

Untuk mengevaluasi terhadap sistem yang sudah dibangun, untuk dapat melihat sejauh mana tingkat keberhasilan fungsionalitas program, dalam hal ini menggunakan metode black box. Hasil evaluasi diperlihatkan pada tabel 1 .

Dari tabel hasil uji evaluasi aplikasi diatas, secara umum $100 \%$ tampilan dan menu sudah sesuai dan berjalan sesuai dengan fungsionalitas yang diharapkan. 
TABEL I

Hasil Evaluasi Black BoX Testing PADA APLIKASI

\begin{tabular}{|c|c|c|c|}
\hline $\begin{array}{l}\text { Komponen } \\
\text { Pengujian }\end{array}$ & $\begin{array}{l}\text { Output yang } \\
\text { Diharapkan }\end{array}$ & $\begin{array}{c}\text { Hasil } \\
\text { Keluaran }\end{array}$ & Kesimpulan \\
\hline $\begin{array}{l}\text { Halaman } \\
\text { Login }\end{array}$ & $\begin{array}{l}\text { User bisa } \\
\text { login dan } \\
\text { masuk ke } \\
\text { menu admin }\end{array}$ & $\begin{array}{l}\text { User bisa } \\
\text { masuk dan } \\
\text { login }\end{array}$ & berhasil \\
\hline $\begin{array}{l}\text { Tampilan } \\
\text { menu } \\
\text { utama }\end{array}$ & $\begin{array}{l}\text { Menampilkan } \\
\text { menu utama } \\
\text { secara } \\
\text { lengkap }\end{array}$ & $\begin{array}{l}\text { Menu utama } \\
\text { website bisa } \\
\text { tampil }\end{array}$ & berhasil \\
\hline $\begin{array}{l}\text { Tampilan } \\
\text { menu profil }\end{array}$ & $\begin{array}{l}\text { Menampilkan } \\
\text { halaman } \\
\text { menu profil } \\
\text { kelurahan }\end{array}$ & $\begin{array}{l}\text { Menu profil } \\
\text { tampil } \\
\text { lengkap }\end{array}$ & berhasil \\
\hline $\begin{array}{l}\text { Tampilan } \\
\text { menu } \\
\text { Agenda }\end{array}$ & $\begin{array}{l}\text { Menampilkan } \\
\text { haaman } \\
\text { menu agenda } \\
\text { kegiatan } \\
\text { kelurahan }\end{array}$ & $\begin{array}{l}\text { Menu } \\
\text { Agenda } \\
\text { dapat } \\
\text { menampilkan } \\
\text { agenda }\end{array}$ & berhasil \\
\hline $\begin{array}{l}\text { Tampilan } \\
\text { menu } \\
\text { Berita }\end{array}$ & $\begin{array}{l}\text { Menampilkan } \\
\text { halaman } \\
\text { menu berita }\end{array}$ & $\begin{array}{l}\text { Menu hlam } \\
\text { berita tampil } \\
\text { sempurna }\end{array}$ & berhasil \\
\hline $\begin{array}{l}\text { Tampilan } \\
\text { menu } \\
\text { Galeri }\end{array}$ & $\begin{array}{l}\text { Menampilkan } \\
\text { halaman } \\
\text { menu gleri } \\
\text { fhoto } \\
\text { kegiatan }\end{array}$ & $\begin{array}{l}\text { Menu galeri } \\
\text { dapat } \\
\text { menampilkan } \\
\text { fhoto-fhto } \\
\text { kegiatan }\end{array}$ & berhasil \\
\hline $\begin{array}{l}\text { Tampilan } \\
\text { menu Form } \\
\text { Pelayanan }\end{array}$ & $\begin{array}{l}\text { Menampilkan } \\
\text { menu form } \\
\text { pelayanan } \\
\text { pembuatan } \\
\text { surat } \\
\text { pengantar }\end{array}$ & $\begin{array}{l}\text { Menu Form } \\
\text { pelayanan } \\
\text { dapat } \\
\text { digunakan } \\
\text { sesuai } \\
\text { fungsinya }\end{array}$ & berhasil \\
\hline $\begin{array}{l}\text { Tampilan } \\
\text { menu } \\
\text { Hubungi } \\
\text { Kami }\end{array}$ & $\begin{array}{l}\text { Menampilkan } \\
\text { menu } \\
\text { hubungi kami } \\
\text { secara } \\
\text { lengkap }\end{array}$ & $\begin{array}{l}\text { Menu } \\
\text { halaman } \\
\text { hubungi } \\
\text { kami tampil }\end{array}$ & berhasil \\
\hline
\end{tabular}

\section{KESIMPULAN}

Dari hasil penelitian terkait dengan implementasi $e$ Government pada kelurahan Pesurungan Lor Kota Tegal dengan menggunakan SOA sebagai basisnya, dapat diambil kesimpulan sebagai berikut:

- E-Government merupakan salah satu solusi terbaik dalam upaya peningkatan pelayanan administrasi pemerintahan khususnya di wilayah kelurahan Pesurungan Lor Kota Tegal kepada masayarakat sehingga menjadi lebih baik dan lebih efisien.

- Service Oriented Architecture (SOA) merupakan model sistem yang menjadi teknologi terintegrasi dengan aplikasi e-Government yang digunakan untuk bisa menuju kepada konsep web service, dimana konsep ini memungkinkan setiap aplikasi sistem $e$-Government dapat terintegrasi.

Untuk penelitian selanjutnya perlu adanya sebuah pengembangan $e$-Government yang terintegrasi antara SOA dan web service sehingga sistem yang telah ada dapat terintegrasi dengan aplikasi e-Government lainnya.

\section{DAFTAR PUSTAKA}

[1] Hasibuan, Z.A. and Santoso, H.B., 2005. Standardisasi Aplikasi EGovernment Untuk Instansi Pemerintah. Prosiding Konferensi Nasional Teknologi Informasi dan Komunikasi Indonesia ITB (hal. 42 48). Bandung: ITB.

[2] Sabucedo, L. M. Á., Rifón, L. E. A., Pérez, R. M., \& Gago, J. M. S 2009. Providing standard-oriented data models and interfaces to eGovernment services: a semantic-driven approach. Computer Standards \& Interfaces, 31(5), 1014-1027.

[3] Istiyanto, J.E. and Sutanta, E., 2012. Model Interoperabilitas Antar Aplikasi e-Government. Jurnal Technoscientia, 5.

[4] Lisboa, A. and Soares, D., 2014. E-Government interoperability frameworks: a worldwide inventory. Procedia Technology, 16 , pp.638-648

[5] Handayani, P.W. and Kardia, N.P., 2012. Analisis Tingkat Implementasi E-government pada Level Kementerian Indonesia Berdasarkan Framework Deloitte \& Touche. Jurnal Sistem Informasi, 6(2), pp.134-139

[6] Sosiawan, E.A., 2015, June. Evaluasi Implementasi E-Government Pada Situs Web Pemerintah Daerah Di Indonesia: Prespektif Content Dan Manajemen. In Seminar Nasional Informatika (SEMNASIF) (Vol. 1, No. 5).

[7] Papazoglou, M.P., Traverso, P., Dustdar, S. and Leymann, F., 2008 Service-oriented computing: a research roadmap. International Journal of Cooperative Information Systems, 17(02), pp.223-255.

[8] Fajar, Ahmad Nurul, Eko K. Budiardjo, and Zainal A. Hasibuan. 2013 Penerapan ZEF Framework untuk Aplikasi E-Government: Pendekatan Sinergi BPM (Business Process Model) dan SOA (Service Oriented Architecture). Seminar Nasional Aplikasi Teknologi Informasi (SNATI).

[9] Shofa, A.R.N., Kurnia, B. B., 2013. Penerapan Service Oriented Architecture Untuk Pembangunan Web Based Learning. Jurnal Penelitian Sitrotika. Volume 9. Nomor 2.

[10] Perdananugraha, G.M., 2012. Rancang Bangun Dan Implementasi Sistem Informasi Terintegrasi (Integrated Information System) EGovernment Berbasis Open Source. Jurnal Teknologi Indonesia (JTI), $33(1)$

[11] Sutanta, E. and Mustofa, K., 2012. Kebutuhan Web Service Untuk Sinkronisasi Data Antar Sistem Informasi Dalam E-Gov Di Pemkab Bantul Yogyakarta. JURNAL TEKNOLOGI INFORMASI \& KOMUNIKASI (JURTIK), 1(1).

[12] Stoica, E.A., Pitic, A.G. and Mihăescu, L., 2013. A Novel Model for E-Business and E-Government Processes on Social Media. Procedia Economics and Finance, 6, pp.760-769.

[13] Sabucedo, L.M.A., Rifón, L.E.A Pérez, R.M and Gago, J.M.S., 2009 Providing standard-oriented data models and interfaces to eGovernment services: A semantic-driven approach. Computer Standards \& Interfaces. 31. pp.1014-1027

[14] Rahardjo, Budi., 2001. Membangun eGovernment. Bandung: Informatika

[15] United Nations. Benchmarking e-government: A global perspective. Web available, 2008. [online], http://www.unpan.org/Library/MajorPublications/UNEGovernmentSur vey/PublicEGovernanceSurveyintheNews/tabid/651/mctl/ArticleView/ 
ModuleId/1555/articleId/22305/Government-to-Egovernment-toEsociety.aspx, tanggal akses: Desember 2016.

[16] Pascual, P.J., 2003, e-Government, eAsean Task Force UNDPAPDIP, May 2003

[17] A. Ordanini and P. Pasini., 2008. Service co-production and value cocreation: The case for a service-oriented architecture (SOA),"
European Management Journal, vol. 26, pp. 289-297.

[18] Erl, Thomas. Service Oriented Architecture: Concepts, Technology and Design. Indiana: Prentice Hall PTR. 2005

[19] Delphi. G.: SOA: a business architecture for managing uncertainty. USA: Delphi Group, 2005. 